\title{
DESENSITIZATION OF THE HUMAN MOTILIN RECEPTOR BY
}

\section{MOTILIDES}

Leen Thielemans, Inge Depoortere, Jason Perret, Patrick Robberecht, Yaoquan Liu, Theo Thijs, Chris Carreras, Emmanuel Burgeon, Theo L. Peeters.

Gut Hormone Lab, Center for Gastroenterological Research, Department of Pathophysiology, Katholieke Universiteit Leuven, Leuven B-3000, Belgium L.T.; I.D.; T.T.; T.L.P.

Department of Biological Chemistry and Nutrition, Faculty of Medicine, Universite Libre de Bruxelles, B-1070 Brussels, Belgium

$$
\text { J.P.; P.R. }
$$

Euroscreen, rue Adrienne Bolland 47, 6041 Gosselies, Belgium

$$
\text { E.B. }
$$

Kosan Biosciences, 3832 Bay Center Place, Hayward, CA 94545, USA

$$
\text { Y.L.; C.C. }
$$


running title: DIFFERENTIAL MOTILIN RECEPTOR DESENSITIZATION.

Address for correspondence:

\title{
T.L. Peeters
}

Gut Hormone Lab

Gasthuisberg O \& N

B-3000 LEUVEN, Belgium

Telephone: + $+32-16-345757$

fax: $\quad+\quad+32-16-345939$

E-mail: theo.peeters@med.kuleuven.ac.be

\# Pages: 33

\# Figures: 8

\# Tables: 1

\# References: 40

\# Abstract: 248

\# Introduction: 405

\# Discussion: 1418

\begin{abstract}
Abbreviations:
MTLR-EGFP: enhanced green fluorescent protein tagged motilin receptor $\mathrm{pDC}_{50}$ : negative logarithm of the concentration producing half maximal desensitization
\end{abstract} Acetylcholine: ACh 


\section{Abstract}

Tachyphylaxis may have contributed to the failure of the motilide ABT-229 in clinical trials. We compared the desensitizing potency of structurally related motilides in a CHO-K1 cell line expressing the human motilin receptor (MTLR) and in rabbit duodenal segments. Methods. CHO-MTLR cells were preincubated with motilides prior to stimulation with motilin. The negative logarithm of the preincubation concentration reducing the maximal motilin-induced $\mathrm{Ca}^{2+}$ flux to $50 \%$ was calculated $\left(\mathrm{pDC}_{50}\right)$. Internalization was visualized in $\mathrm{CHO}-\mathrm{K} 1$ cells containing an EGFP-tagged MTLR and quantified in binding experiments. The contractile response of repeated stimulations was measured in duodenal segments. Results. In CHO-MTLR cells the $\mathrm{pDC}_{50}$ was ABT-229 (8.78)> motilin (7.77)> EM-A (4.78), different from their order of potency to induce $\mathrm{Ca}^{2+}$ release $\left(\mathrm{pEC}_{50}\right)$ : motilin $(9.39)>\mathrm{ABT}-229$ (8.46)>EM-A (7.11). In cells with the EGFP-tagged MTLR, ABT-229 decreased membrane fluorescence by $25 \pm 2 \%$ compared to $16 \pm 2 \%$ for motilin, $8 \pm 2 \%$ for EM-A. Binding studies confirmed that EM-A did not induce MTLR internalization (residual binding $96 \pm 4 \%$ compared to motilin, $31 \pm 3 \%$ and ABT-229, 21 $\pm 1 \%$ ). Comparison of the $\mathrm{pDC}_{50}$ and $\mathrm{pEC}_{50}$ values of the other motilides ME4 (5.90;8.08), ME67 (6.03;8.12), ME36 (3.32;6.62); EM-523 (6.02;8.22) and KOS1326 (7.32;8.14) suggested that the strong desensitizing properties of ABT-229 are mostly related to the removal of the 4"-OH of the cladinose sugar. The decline of the contractile response in duodenal segments correlated with the $\mathrm{pDC}_{50}$. Conclusion. The ability to desensitize and internalize the MTLR is not only determined by potency. This may be an important criterion for the development of a clinically useful compound. 


\section{Introduction}

The finding that the antibiotic erythromycin-A (EM-A) interacts with the motilin receptor (Peeters et al., 1989) became clinically relevant when it was discovered that EM-A accelerated delayed gastric emptying in patients with diabetic gastroparesis (Janssens et al., 1990). As a result, more potent motor stimulating EM derivatives were developed without antibiotic activity: the motilides (Omura et al., 1987). Recently the clinical development of the most promising motilide, ABT-229, was stopped because of its failure to improve symptoms in patients with functional dyspepsia with normal or delayed gastric emptying (Talley et al., 2000), and in patients with type 1 diabetes mellitus (Talley et al., 2001). The authors of the studies with ABT-229 concluded that there was no future for drugs with the prokinetic profile of the motilides, but others have argued that ABT-229 had undesirable properties that may be avoided in new motilides (Tack and Peeters, 2001; Camilleri, 2002). The most important property in this respect is the development of tachyphylaxis. Previous studies described a decreased contractile response of rabbit colonic myocytes due to downregulation of motilin receptors after chronic oral treatment (Bologna et al., 1993) and after short term intravenous treatment with erythromycin A (Depoortere et al., 1991), the parent compound from which ABT-229 was derived. One-month treatment of rabbits with ABT-229 also resulted in a downregulation of motilin receptors and a reduced contractile response to ABT-229 and motilin (Depoortere et al., 1999). Tachyphylaxis was also observed after treatment of healthy subjects with ABT-229. A single dose of ABT-229 increased gastric emptying after the first meal, but emptying of a second meal was not affected although ABT-229 plasma levels were still high (Verhagen et al., 1997). 
Recently, we have shown that the $\mathrm{Ca}^{2+}$ fluxes induced by peptidyl and nonpeptidyl motilin agonists in a $\mathrm{CHO}$ cell line expressing the cloned human motilin receptor and the $\mathrm{Ca}^{2+}$ indicator apoaequorin (CHO-MTLR) correlate strongly with the contractile response of these compounds in rabbit duodenal strips (Thielemans et al., 2002). In the present study we therefore used the aequorin-based luminescence assay to study the desensitization of the motilin receptor by ABT229 in more detail. In order to clarify whether desensitization is a common characteristic of all motilides, the desensitizing properties of several motilides with different structural features were compared. To determine the mechanism underlying desensitization, receptor internalization following application of ABT229 was quantified by receptor binding studies and visualized by using an enhanced green fluorescent protein (EGFP)-tagged motilin receptor (MTLREGFP). 


\section{Methods}

\section{Materials}

Norleucine ${ }^{13}$-porcine-motilin ([Nle $\left.{ }^{13}\right]$ po-motilin) was purchased at Eurogentec (Namur, Belgium) and will further be referred to as motilin.

Erythromycin-A (EM-A), EM-A enol ether (ME4), N-ethyl, N-methyl EM-A (ME36), EM-B enol ether (ME67) and N-ethyl, N-methyl EM-A enol ether (EM523) were obtained from prof. J. Hoogmartens (Laboratory of Pharmaceutical Chemistry, University of Leuven, Belgium). N-ethyl, N-methyl 4" deoxy EM-B enol ether (ABT229) was a gift from Dr.P.Lartey (Lartey et al., 1995; Abbott Laboratories, Abbott Park, Illinois, USA). Macrolide KOS1326 was a synthesized by Kosan Biosciences, Inc. (Hayward, CA, USA).

\section{Cell Culture}

A Chinese hamster ovary cell line (CHO-K1) stably expressing the human motilin receptor and the mitochondrially-targeted apoaequorin was obtained from Euroscreen (Brussels, Belgium). The cells were cultured in Ham's F12 containing $10 \%$ FBS, $100 \mu \mathrm{g} / \mathrm{ml}$ streptomycin, $2.5 \mu \mathrm{g} / \mathrm{ml}$ amphotericin B (Gibco BRL, Grand Island, NY), $400 \mu \mathrm{g} / \mathrm{ml} \mathrm{G418} \mathrm{and} 5 \mu \mathrm{g} / \mathrm{ml}$ puromycin (Sigma, St. Louis, MO., USA) and spliced once a week with $5 \mathrm{mM}$ EDTA in PBS.

\section{Calcium measurements: Aequorin luminescence assay}

Suspended cells $\left(5 \times 10^{6}\right.$ cells $\left./ \mathrm{ml}\right)$ were loaded with coelenterazine $\mathrm{h}(5 \mu \mathrm{M})$ (Molecular Probes, Leiden) at room temperature for at least 4 hours, in order to reconstitute active aequorin. Cells were then diluted 10-fold with 'BSA-medium' (DMEM/Ham's F12 with Hepes, without phenol red, $0.1 \%$ BSA, $100 \mathrm{IU} / \mathrm{ml}$ 
penicillin, $100 \mu \mathrm{g} / \mathrm{ml}$ streptomycin, $2.5 \mu \mathrm{g} / \mathrm{ml}$ amphotericin B) and $100 \mu \mathrm{l} /$ well was injected (50 000 cells) into a 96 well-plate containing increasing concentrations of the test compound diluted in BSA-medium.

Immediately after injection of cells, the emitted light was measured using the 'Microlumat plus' luminometer (Berthold, Bad Wildbad, Germany) during 20 seconds. The intensity of the emitted light was integrated using the Winglow software (Berthold), yielding for each well one value representative of the emitted light and hence of the stimulation of the motilin receptor by the agonist present in the well. This value was expressed as a percentage of maximal stimulation obtained with Triton-X 100 (0.9\%). All values were corrected for background by subtracting the blanc value (= BSA-medium). The negative logarithm of the concentration producing half of the maximal response $\left(\mathrm{pEC}_{50}\right)$ was calculated from the dose-response curves by linear interpolation. All experiments were performed in duplicate and each compound was tested at least 2 times. Results are represented as mean \pm standard error of the mean (SEM).

To assess desensitization, cells were pre-treated for at least one hour with different concentrations of agonist during loading, washed and centrifuged before dose response curves were established with motilin. The effect of pretreatment on the maximal response was assigned as the effect of desensitization. The average of the maximal plateau values of the dose response curve to motilin under desensitizing conditions was expressed as a percentage of maximal response under control conditions. The potency of a compound to induce desensitization was calculated after plotting the remaining maximal responses as a function of the concentration of the compound used to desensitize. A sigmoid concentration response curve was fitted through the data by non-linear regression analysis using 
the Graphpad Prism software (San Diego, CA, USA) and a $\mathrm{pDC}_{50}$ value and its standard error of the best fit value (negative logarithm of the concentration producing half maximal desensitization) was calculated. For each compound delta values were calculated by subtraction of $\mathrm{pEC}_{50}$ values with $\mathrm{pDC}_{50}$ values. The square root of the sum of squares of the standard deviation $\left(\mathrm{SEM}\right.$ for $\mathrm{pEC}_{50}$ ) and the standard error of the best-fit value $\left(\mathrm{SE}\right.$ for $\left.\mathrm{pDC}_{50}\right)$ resulted in the standard deviation of these delta values. A pooled standard deviation $\left(s_{p}\right)$ was derived from which a t-value was calculated for the comparison of two delta values, with $\mathrm{n}_{1}+$ $\mathrm{n}_{2}-2$ degrees of freedom using:

$$
t_{0}=\frac{\bar{x}_{1}-\bar{x}_{2}}{s_{p} \sqrt{\frac{1}{n_{1}}+\frac{1}{n_{2}}}}
$$

\section{Receptor binding studies}

Membrane preparation

CHO-K1 cells expressing the MTLR were cultured till $90 \%$ confluence was reached. After removal of medium, cells were scraped from the plates in $\mathrm{Ca}^{2+} / \mathrm{Mg}^{2+}$ free PBS. After centrifugation for $3 \mathrm{~min}$ at $1500 \mathrm{~g}$, pellets were resuspended in a buffer containing $15 \mathrm{mM}$ Tris- $\mathrm{HCl} \mathrm{pH} 7.5 ; 2 \mathrm{mM} \mathrm{MgCl}_{2} ; 0.3$ mM EDTA; $1 \mathrm{mM}$ EGTA and homogenized in a glass homogenizer. The crude membrane fraction was collected by two consecutive centrifugation steps at $40.000 \mathrm{x} \mathrm{g}$ for $25 \mathrm{~min}$ separated by a washing step in the same buffer. The final pellet was resuspended in a buffer containing $7.5 \mathrm{mM}$ Tris- $\mathrm{HCl} \mathrm{pH} 7.5 ; 12.5 \mathrm{mM}$ $\mathrm{MgCl}_{2} ; 0.3 \mathrm{mM}$ EDTA; $1 \mathrm{mM}$ EGTA; $250 \mathrm{mM}$ sucrose, and flash frozen in liquid nitrogen.

The protein content was determined by the Folin method (Lowry et al., 1951). 
Cell membrane receptor binding

Competition binding assays were performed by incubating CHO-MTLR membranes $\left(8 \mu \mathrm{g}\right.$ of protein/tube) in a final volume of $0.1 \mathrm{ml}$ with ${ }^{125} \mathrm{I}$-motilin $(0.3$ $\mathrm{nM}$ ) for 60 minutes at $31^{\circ} \mathrm{C}$. Unlabelled motilin, motilin fragments and motilides were used as competitors, at concentrations ranging from $10^{-12}$ to $10^{-4} \mathrm{M}$ in binding buffer (25 mM Hepes pH 7.4; $1 \mathrm{mM} \mathrm{CaCl}_{2} ; 5 \mathrm{mM} \mathrm{MgCl} 2 ; 0.5 \% \mathrm{BSA}$ ). After incubation, the samples were filtered on GF/B filters, washed and counted in a gamma counter. All values were corrected for non-specific binding determined by addition of an excess $\left(10^{-5} \mathrm{M}\right)$ of unlabelled motilin. $\mathrm{IC}_{50}$ values were determined by non-linear regression using a single-site model (PRISM, Graph Pad Software Inc., San Diego). Each compound was tested three times in duplicate.

Construction and expression of the MTLR coding sequence, as a N-terminal fusion protein, with the enhanced green fluorescent protein (EGFP)

The cDNA for the full coding sequence, inserted in the pcDNA3.1 vector (Provided by Euroscreen SA, Brussels, Belgium), was amplified by PCR using the proof reading taq polymerase $P f u$ Turbo (Stratagene, La Jolla, Ca, USA). The 5' primer contained the XhoI restriction site followed by a Kozak consensus sequence preceding the ATG initiation codon and 18 gene specific nucleotides. The 3' primer contained a 5' EcoRI restriction site followed by the 26 terminal nucleotides of the coding sequence, the TGA stop codon being mutated to remove the translation termination signal and provide an in phase sequence with the EGFP coding sequence that follows immediately the multiple cloning site in the pEFGP plasmid (BD Biosciences Clontech, Palo Alto, Ca, USA). The PCR product was digested by DpnI restriction enzyme to remove parental target DNA, purified on Qiaquick PCR purification columns (Qiagen GmbH, Hilden, Germany) and 
digested by XhoI \& EcoRI. The pEFGP plasmid was digested in the same manner. The digestion products were purified on Qiaquick PCR purification columns and an aliquot of the resulting $50 \mu \mathrm{l}$ was run on a $0.8 \%$ TAE agarose gel. A fraction of the digestion products, i.e. the motilin coding sequence and the pEFGP vector, were mixed and dried in a speed vacuum concentrator. The dried DNA was resuspended, ligated with $\mathrm{T}_{4}$ DNA ligase (Promega Corporation, Wi, USA) and transformed into TOP10 One Shot Ultracompetent E. Coli bacterial host cells according to manufacturers instructions (Invitrogen Corporation, Carlsbad, California). Several colonies were picked; miniprep DNA was prepared using the GFX micro plasmid preparation kit (Amersham Pharmacia Biotech, NJ, USA), and the presence of an insert was verified by gel electrophoresis. Three clones were checked by automated DNA sequencing on an ABI machine using Big Dye Terminator chemistry. One clone was then amplified using the GenElute Endotoxin Free Midi Prep kit (Sigma-Aldrich, MI, USA). Transfection of $20 \mu \mathrm{g}$ purified plasmid DNA was carried out by electroporation (Electroporator II, Invitrogen) according to manufacturer instructions, into CHO-PAM28 cells CHO cells stably expressing the aequorine gene (Euroscreen SA, Brussels, Belgium). After selection by G418 (Life Technologies) 24 individual clones were picked and further amplified for functional characterization.

\section{Visualization of endocytosis of the MTLR-EGFP}

CHO cells containing the MTLR-EGFP were grown on 4 well coverglass chambers until $80 \%$ confluency. After washes with ice-cold BSA medium, digital pictures were made with an Olympus camera on an inverted NIKON microscope (40x oil) equipped with a fluorescence unit and filtered with filtercube B-2A (EX BP540-580, DM RK595, EM BA 600-610). BSA-medium containing $10^{-5} \mathrm{M}$ of 
the compound of interest was added, after which the cells were gently shaken at $4{ }^{\circ} \mathrm{C}$ for $1 \mathrm{~h}$ for equilibration binding, followed by $1 \mathrm{~h}$ incubation at $37^{\circ} \mathrm{C}$. Internalization was stopped by washing the cells with ice-cold PBS. Pictures of the same cells were taken. For quantification the fluorescent grayscale pictures were converted to black and white. The percentage black and white at the membrane and in the cytosol was calculated for 10 cells per condition before and after stimulation using Scion Image (Scion Corporation, MD, USA) and compared to control. Each condition was evaluated in 3 different experiments. Means were compared using an unpaired t-test (PRISM, Graph Pad Software Inc., San Diego).

\section{Quantification of MTLR-EGFP internalization}

The capacity of different compounds to promote internalization was examined by adding the compound of interest $\left(10^{-5} \mathrm{M}\right)$ to the $\mathrm{CHO}$ cells containing the MTLREGFP in 12-well plates for $60 \mathrm{~min}$ at $37^{\circ} \mathrm{C}$. Surface-bound ligands were removed with a gentle acid wash $(50 \mathrm{mM}$ sodium citrate, $0.2 \mathrm{mM}$ sodium phosphate, 90 $\mathrm{mM} \mathrm{NaCl}, 0.1 \%$ bovine serum albumin, $\left.\mathrm{pH} 5.0 ; 10 \mathrm{~min}, 4^{\circ} \mathrm{C}\right)$, which does not affect subsequent receptor binding, and then a radioreceptor binding assay was performed $\left({ }^{125} \mathrm{I}\right.$-motilin, $0.3 \mathrm{nM}, 4 \mathrm{~h}$ at $\left.4^{\circ} \mathrm{C}\right)$ to measure receptors remaining at the cell surface. Internalized receptors were expressed as a percentage loss of cell surface binding compared with cells not exposed to the compound of interest. Means \pm SEM were compared using an unpaired t-test (PRISM, Graph Pad Software Inc., San Diego).

\section{Contractility studies}

Integral rabbit duodenal segments $(1.5-2 \mathrm{~cm})$ were vertically suspended in tissue baths containing Hepes-buffer pH 7.4 (Hepes $11.6 \mathrm{mM}$, glucose $11.5 \mathrm{mM}, \mathrm{NaCl}$ 
$137 \mathrm{mM}, \mathrm{KCl} 5.9 \mathrm{mM}, \mathrm{CaCl}_{2} 1.2 \mathrm{mM}, \mathrm{MgCl}_{2} 1.2 \mathrm{mM}$ ) continuously gassed with $100 \% \mathrm{O}_{2}$ and kept at $37^{\circ} \mathrm{C}$. Contractions were recorded isotonically using HP 7DCDT-1000 transducers from Hewlett-Packard Co (Palo Alto, CA) and a displacement control unit obtained from Janssen Scientific Instrument Division (Beerse, Belgium). Signal output was connected to a recorder and to a computer and sampled for digital analysis using the Windaq data acquisition system and a DI-2000 PGH card (Dataq Instruments, Akron, Ohio, USA).

Strips were equilibrated in the tissue bath until a stable response to acetylcholine (ACh, $0.1 \mathrm{mM}$ ) was obtained. Strips were then stimulated with either ABT-229 (69 nM), KOS1326 (0.17 $\mu \mathrm{M})$, EM-A $(14.1 \mu \mathrm{M})$, ME4 $(0.44 \mu \mathrm{M})$ or EM-523 (66 $\mathrm{nM}$ ) at a concentration corresponding to 5 times their potency to induce contractions. After 4 min, strips were washed-out two times and washed again 2', 6' and 10' after the first wash-out. The washing procedure was then repeated every 10 min until $1 \mathrm{~h}$ after the application of the agonists. Strips were then stimulated for a second time with the compound of interest and washed again according to the procedure described above. After the third application, strips were not washed-out but a supramaximal dose of motilin $(1 \mu \mathrm{M})$ followed by a supramaximal dose of $\mathrm{ACh}(0.1 \mathrm{mM})$ was applied. Desensitization was expressed as a $\%$ of the response of the agonists obtained after the first application. The response to motilin at the end of the experiment was expressed relative to the response to $\mathrm{ACh}$.

All experiments were approved by the Ethical committee of the University of Leuven. 


\section{Results}

\section{Desensitization of the motilin receptor}

Desensitization of the motilin receptor was induced by prestimulation of $\mathrm{CHO}$ MTLR cells with different concentrations $\left(10^{-12}, 10^{-9}, 10^{-8}, 10^{-7}, 10^{-6}, 10^{-5} \mathrm{M}\right)$ of motilin. This reduced the maximal response in a subsequent concentration response curve to motilin to resp. $97.2 \pm 1.3,83.9 \pm 7.8,64.9 \pm 1.3,3.8 \pm 1.3,2.8$ \pm 0.9 and $1.6 \pm 1.3 \%$ (Figure 1$)$.

Next, motilin's ability to desensitize was compared with that of the motilides ABT-229 and EM-A. These compounds are structurally related but differ at four positions, as illustrated in Figure 2A.

Both agonists were tested at $10^{-5} \mathrm{M}$, a concentration sufficient to evoke a maximal $\mathrm{Ca}^{2+}$ luminescent response. However, following pretreatment at this concentration, there was a marked difference in the maximal response to a subsequent stimulation to motilin, which was reduced to $65.8 \pm 1.8 \%$ for EM-A and to $-0.2 \pm$ $0.4 \%$ for ABT-229. The desensitizing capacity of ABT-229 but not of EM-A was therefore comparable to that of motilin.

In order to investigate which structural elements underlie the stronger desensitizing potency of ABT-229 in comparison to EM-A, several EM-A derivatives were tested, containing one or two ABT-229-like modifications (Figure 2B). The modifications include the presence of an enol-configuration (ME4, ME67, EM-523, KOS1326), the presence of an ethyl group at the amine group of the desosamine sugar (ME36, EM-523), and the lack of a hydroxyl at position 12 of the lactone ring (ME67) or at position 4', of the cladinose sugar (KOS1326). 
Figure 3 shows that compounds with an enol configuration such as ABT-229, ME4, EM-523, ME67 and KOS1326, induced a more profound desensitization at $10^{-5} \mathrm{M}$ than EM-A. In contrast desensitization was seemingly absent with ME36 which, compared to EM-A, contains only a modification at the amine group of the desosamine sugar.

However, the enol configuration also increases the potency of motilides to induce contractions in muscle strips and to induce a $\mathrm{Ca}^{2+}$ flux in the CHO-MTLR cells (Depoortere et al., 1989; Thielemans et al., 2002). Therefore, although the pretreatment concentration was sufficient to induce a maximal response for all compounds tested, one could argue that less potent compounds may require higher pretreatment concentrations. In order to fully discriminate between potency and ability to desensitize, we therefore established a "concentration response curve of desensitization" for each motilide. Figure 4 shows the effect of pretreatment of the CHO-MTLR cells with increasing concentrations of motilin, EM-A or ABT-229 on the maximal response to a subsequent concentration response curve to motilin. From these curves, the pretreatment concentration which reduces the maximal response to $50 \%$ of the control value was calculated. The negative logarithm of this concentration, $\mathrm{pDC}_{50}(-\log [$ Desensitizing Concentration $50 \%]$ reflects the potency to desensitize. The values for all motilides tested are shown in Table 1. This table also lists the potencies of these compounds to induce $\mathrm{Ca}^{2+}$ fluxes ( $\mathrm{pEC}_{50}$ values) in untreated cells (Thielemans et al., 2002).

Although ABT-229 is 8.5 times less potent than motilin in activating the cells $\left(\mathrm{pEC}_{50}: 8.46 \pm 0.08\right.$ versus $\left.9.39 \pm 0.03\right)$, it is 10.2 times more potent in inducing desensitization $\left(\mathrm{pDC}_{50}: 8.78 \pm 0.03\right.$ versus $\left.7.77 \pm 0.08\right)$. Thus, potency does not seem to solely determine the ability to desensitize. To further illustrate this point 
Table 1 shows the difference between the $\mathrm{pDC}_{50}$ and $\mathrm{pEC}_{50}$ values, referred to as delta-value.

Five compounds have a similar delta value (motilin, $1.62 \pm 0.15$; EM-A, $2.33 \pm$ 0.28; ME4, $2.18 \pm 0.42 ;$ ME67, $2.09 \pm 0.25 ;$ EM-523, $2.20 \pm 0.28$ ), indicating that there is a relationship between potency and desensitizing ability (Pearson r: 0.9054). However for ABT-229 and KOS1326, the delta value is significantly lower than in these compounds $(\mathrm{p}<0.01)$ and for ME36 it is significantly higher $(\mathrm{p}<0.01)$.

\section{Binding of motilides with the MTLR}

As both activation and desensitization result from the interaction of the ligand with its receptor, we investigated whether the higher than expected ability of ABT-229 and KOS1326 to desensitize could be explained by a higher affinity for the motilin receptor. The $\mathrm{pIC}_{50}$ values (Table 1) calculated from the displacement curves did not reveal an increased affinity neither for ABT-229 nor for KOS1326.

\section{Comparison of MTLR-EGFP and wild type receptor}

As desensitization involves receptor internalization, an EGFP-tagged motilin receptor was generated and stably expressed in $\mathrm{CHO}$ cells to follow receptor trafficking. The cells also expressed the $\mathrm{Ca}^{2+}$ indicator apoaequorin (MTLREGFP), which allowed us to determine whether GFP interfered with signal transduction and desensitization.

Both for the wild type receptor and the MTLR-EGFP the order of potency to induce $\mathrm{Ca}^{2+}$ release is: motilin>ABT-229>EM-A (Figure 5A). The absolute potency $\left(\mathrm{pEC}_{50}\right)$ of all compounds is $9.17 \pm 1.14$ (motilin), $8.12 \pm 0.17$ (ABT- 
229), and $6.45 \pm 0.08$ (EM-A) in the MTLR-EGFP and is somewhat lower than in the MTLR.

Pretreatment of MTLR-EGFP with $10^{-5} \mathrm{M}$ motilin, ABT-229 or EM-A reduced the response to a subsequent stimulation with motilin to respectively $18.7 \pm 2.5 \%$, $2.9 \pm 1.3 \%$ and $99.2 \pm 8.5 \%$ (Figure 5B). These effects are less pronounced than in the wild type receptor but the discrepancy between activation and desensitization remains, as ABT-229, although less potent than motilin, desensitizes most at $10^{-5} \mathrm{M}$.

\section{Internalization of the EGFP-tagged MTLR}

In cells expressing the EGFP-tagged receptor changes in the fluorescence distribution after stimulation with the ligands at $10^{-5} \mathrm{M}$ were studied by fluorescence microscopy. Images obtained before and after stimulation are shown in Figure 6A.

Before the start of the experiment, MTLR-EGFP was principally localized at the plasma membrane. After $1 \mathrm{~h}$ stimulation at $37^{\circ} \mathrm{C}$ in the presence of the motilin agonists, the intensity of the signal at the cell surface was reduced, especially for motilin and ABT-229, and was concentrated in the cytosol.

The images were analysed and the percentage change in fluorescence in the cytosol and in the membrane owing to stimulation was calculated (Figure 6B). All agonists induced a significant increase of cytosolic and a significant decrease of membrane fluorescence compared to control $(\mathrm{p}<0.005)$. The cytosolic increases were similar for motilin, ABT-229 and EM-A (resp $22 \pm 2,25 \pm 2,20 \pm 2, \%$, $\mathrm{p}<0.0001$ vs. control). In contrast, ABT-229 (25 $\pm 2 \%)$ decreased membrane fluorescence significantly more compared to motilin $(16 \pm 2 \%, \mathrm{p}<0.01)$, which in turn induced a more significant decrease compared to EM-A $(8 \pm 2 \%, \mathrm{p}<0.01)$. 


\section{Radioligand binding with the EGFP-tagged MTLR}

To validate the semi-quantitative data of the analysis of the fluorescence distribution, the more quantitative method of receptor binding was used to measure ligand-induced endocytosis. Radioligand binding with ${ }^{125} \mathrm{I}$-motilin was performed after pretreatment of MTLR-EGFP with $10^{-5} \mathrm{M}$ motilin, ABT-229 or EM-A for 20 and $60 \mathrm{~min}$ at $37^{\circ} \mathrm{C}$ (Figure 7). Residual binding after $20 \mathrm{~min}$ prestimulation was $44.9 \pm 2.3 \%$ (motilin), $30.8 \pm 3.8 \%$ (ABT-229), $124.3 \pm 2.0 \%$ (EM-A) and was further reduced to respectively $30.8 \pm 3.3 \%(\mathrm{p}=0.0029), 21.3 \pm$ $0.8 \%(\mathrm{p}<0.0001)$ and $96.1 \pm 4.4 \%(\mathrm{p}<0.0001)$ after prestimulation for $60 \mathrm{~min}$. In line with the desensitization data, internalization after prestimulation with ABT-229 was higher $(\mathrm{p}=0.029)$ than after stimulation with motilin or EM-A although all compounds are equipotent at the concentration used for prestimulation. Curiously, prestimulation with EM-A for 20 min induced a significant increase in binding $(124.3 \pm 2.0 \% ; \mathrm{p}<0.0001)$.

\section{Contractility studies}

The desensitizing properties of ABT-229, KOS1326, EM-A, ME4 and EM-523 were also compared in vitro in the tissue bath, by determining the contractile response of segments of rabbit duodenum to 3 applications with one hour interval. Figure 8 shows that for all compounds the contractile response decreases, but the effect was most pronounced with ABT-229: the third application resulted in a contraction that was only $8.92 \pm 0.96 \%$ of its first application. EM-A is at the other end with $86.50 \pm 4.22 \%(\mathrm{n}=3)$. Compounds EM-523 and ME4 showed a comparable decrease after the third application (56.58 \pm 4.71 and $55.20 \pm 8.86 \%$ resp.; $n=4)$. 


\section{Discussion}

Our study shows that motilides desensitize the motilin receptor to different extents, related to their ability to activate the release of $\mathrm{Ca}^{2+}$. However, this does not apply to all motilides since ABT-229 has a much stronger desensitizing potency than may be expected from its activity or from its binding affinity, suggesting that for some motilides activation and desensitization are partially decoupled. The more profound desensitization was also translated in an enhanced internalization of the motilin receptor to the cytosol following stimulation with ABT-229 as was evidenced by radioligand binding and by using an EGFP-tagged MTLR. A comparison of the effect of structural changes on changes in activity and desensitization suggests that the removal of the hydroxyl at position 4" of the cladinose sugar contributes most to the strong desensitizing properties of ABT229 , although a combination with other structural changes may be required. One may question the relevance of the model we developed to study desensitization, as CHO-cells, although convenient, may have different activation pathways than gastrointestinal smooth muscle. However, the data we obtained in the tissue bath using the classical model to study the potency of motilides, the contractile response of the rabbit duodenum, corroborate the conclusions of the cellular model. We thus suggest that the strong desensitizing properties of ABT-229 may have contributed to its clinical failure and that a cellular model may be a convenient way to develop motilides without desensitizing properties.

As a general rule, ligands cause both receptor-mediated signaling and signal desensitization. In the case of GPCRs, a ligand signals by activating its receptor, which in turn activates a second messenger (G-protein) inside the cell. GPCR desensitization involves the uncoupling of receptors from their heterotrimeric $\mathrm{G}$ 
proteins, resulting in the internalization (endocytosis) of receptors to endosomes and down regulation (Ferguson, 2001).

The events of activation and desensitization have been linked in many receptor systems, among which the $\beta$ adrenoceptor has been characterized best (Benovic et al., 1988). Our data confirm that there is indeed a correlation between the ability to activate and desensitize e.g. EM-A is less potent than the enolether derivatives ME4, EM-523, ME67 and also induces less desensitization. However, the results with ABT-229 suggest a decoupling of activation and desensitization. Such discrepancies have also been described for the $\mu$-opioid receptor, which is related to the motilin receptor, in the sense that both receptors can be stimulated by a peptide (motilin vs enkephalin) and by a naturally occurring non-peptide (motilides vs morphine, methadone, etorphine... etc). The desensitization of the $\mu$ opioid receptor mediated by methadone and L- $\alpha$-acetyl methadone was more pronounced than for morphine and was disproportionate to their efficacies (Yu et al., 1997). Furthermore, functional desensitization of the monkey $\mathrm{D}_{1 \mathrm{~A}}$ dopamine receptor cannot be predicted reliably from the agonist potency for stimulating adenylate cyclase (Lewis et al., 1998).

The general paradigm that activation and internalization are coupled, is based on studies on $\beta_{2}$-adrenergic and muscarinic receptors demonstrating that partial agonists cause less internalization than full agonists and the amount of receptor internalization caused by an agonist generally correlates with coupling efficiency to G proteins (Toews and Perkins, 1984; Thompson and Fisher, 1990; Szekeres et al., 1998). Again exceptions have been described (Mahan et al., 1985; Barak et al., 1994). Perhaps the best evidence that $G$ protein coupling is not required for receptor endocytosis is provided by the observation that in S49 murine lymphoma 
cell lines, which either lack $\mathrm{G}_{\mathrm{s}} \alpha$ or have point mutations preventing receptor/G protein interactions, $\beta_{2} \mathrm{AR}$ internalization in response to agonist stimulation is normal (Mahan et al., 1985).

In our data, the discrepancy between activation and desensitization is translated into a discrepancy between activation and internalization. Similarly, observations with the $\delta$ - and $\mu$-opioid receptor in transfected cells and enteric neurons in intact animals show that both peptidyl (enkephalin) and non-peptidyl (etorphine) agonists stimulate receptor endocytosis in the expected manner. Remarkably the high affinity $\mu$-opioid receptor agonist, morphine, does not cause detectable internalization, even at concentrations that strongly inhibit adenylate cyclase (Keith et al., 1996; Sternini et al., 1996).

Our results indicate that desensitization and internalization of the motilin receptor are coupled, in line with the paradigm. However, recently it was shown, in the same cellular context, that morphine does desensitize the $\mu$ opioid receptor without causing internalization (Borgland et al., 2003) (2003). It has therefore been suggested that receptor endocytosis is a mechanism for resensitization and down-regulation rather than desensitization (Tsao et al., 2001). As the motilin receptor in our study is stimulated for $1 \mathrm{~h}$ to cause desensitization, it cannot be excluded that the activity that is still measured is the sum of desensitization, internalization, resensitization and down-regulation.

All of these apparently diverse effects can be accounted for in terms of the "ensemble theory" (Kenakin, 2002a-b). This theory states that a receptor can adopt numerous conformations, each unfolding and exposing different regions to the intracellular apparatus, and each associated with specific functions (activation, desensitization, internalization ...). These conformations may differ, even for 
ligands with similar affinity and related structures, and may lead, for example, to different desensitizing properties despite similar activation potencies. Apparently our data illustrate this point, as ABT-229, structurally closely related to EM-523, ME 4, ME 67, and with a comparable potency, causes stronger desensitization. Our data also suggest that the presence of an ethyl at the amine group of the desosamine sugar, as in ME36, reduces the desensitizing ability while removal of the hydroxyl at position 4" of the cladinose sugar, as in ABT-229 and KOS1326, but not at position 12 of the lactone ring, as in ME-67, causes an increase.

Internalization was also measured by receptor binding studies. Prestimulation with EM-A induced receptor upregulation. An increase in receptor density after ligand stimulation, has been demonstrated for A1 adenosine receptors after antagonist treatment (Ciruela et al., 1997) and inverse agonists can up-regulate histamine H2 receptors (Alewijnse et al., 1998), cannabinoid receptors (Bouaboula et al., 1999) and opioid receptors (Zaki et al., 2001). Both agonist and antagonist treatment have been shown to upregulate dopamine receptors (Filtz et al., 1994; Zhang et al., 1994; Geurts et al., 1999).

Our data support the hypothesis that tachyphylaxis might underlie the disappointing outcome of motilides in clinical trials. Internalization of the motilin receptor might explain why the high blood levels of ABT-229 were not able to induce gastric contractions and hence accelerate gastric emptying of a second meal in healthy subjects (Verhagen et al., 1997). However, the effects of ABT-229 have not just been described as non-existent, moreover a worsening of symptoms has been reported by patients with functional dyspepsia (Talley et al., 2000) and diabetic gastroparesis (Talley et al., 2001). This might lead to the conclusion that ABT-229 is still active (Camilleri, 2002) after a 4-week treatment, apparently 
contradicting the occurrence of tachyphylaxis. This paradox might be resolved if one considers the long-term action of ABT-229 as the induction of desensitization rather than activation. Indeed, when motilin receptors are not present on the cell surface, even endogenous motilin will not be able to induce contractions. The observation that less antral contractions after a second meal occur in healthy volunteers treated with ABT-229 compared to placebo (Verhagen et al., 1997) is consistent with this hypothesis. A down-regulation of motilin receptors has also been shown in rabbits that had been treated with ABT-229 for 4 weeks (Depoortere et al., 1999). Whether this underlies the worsening of symptoms has still to be proven as gastric emptying and antral contractility have not been measured at the end of both studies by Talley et al. (Talley et al., 2000; Talley et al., 2001). Besides gastric emptying, impaired accommodation and hypersensitivity are also considered as underlying pathophysiological mechanisms that can be targeted for treatment of dyspeptic patients. A higher tone, increased intensity and frequency of spontaneous contractions in the proximal stomach and a reduction of meal-induced relaxation have been described for erythromycin (Bruley des Varannes et al., 1995; Piessevaux et al., 2001; Distrutti et al., 1999). It has therefore been pointed out that the worsening of symptoms might also be due to an effect of ABT-229 on gastric fundus relaxation (Tack and Peeters, 2001). Combining both hypotheses, the adverse effects might be caused by (acute) spatial non-specific action of ABT-229 action in decreasing fundus relaxation and by (chronic) functional non-specific action in decreasing antral motility by tachyphylaxis.

In conclusion, our data suggest that it should be possible to develop motilides with high potency and less desensitizing ability. Therefore it seems indicated that 
before attempting large-scale clinical trials, the desensitizing potency of a motilide should be evaluated. 


\section{References}

Alewijnse AE, Smit MJ, Hoffmann M, Verzijl D, Timmerman H, and Leurs R (1998) Constitutive activity and structural instability of the wild-type human H2 receptor. J Neurochem 71:799-807.

Barak LS, Tiberi M, Freedman NJ, Kwatra MM, Lefkowitz RJ, and Caron MG (1994) A highly conserved tyrosine residue in G protein-coupled receptors is required for agonist-mediated beta 2 -adrenergic receptor sequestration. $J$ Biol Chem 269:2790-2795.

Benovic JL, Bouvier M, Caron MG, and Lefkowitz RJ (1988) Regulation of adenylyl cyclase-coupled beta-adrenergic receptors. Annu Rev Cell Biol 4:405-28.

Bologna SD, Hasler WL, and Owyang C (1993) Down-regulation of motilin receptors on rabbit colon myocytes by chronic oral erythromycin. J Pharmacol Exp Ther 226:852-856.

Borgland SL, Connor M, Osborne PB, Furness JB, and Christie MJ (2003) Opioid agonists have different efficacy profiles for $G$ protein activation, rapid desensitization, and endocytosis of mu-opioid receptors. J Biol Chem 278:1877618784.

Bouaboula M, Dussossoy D, and Casellas P (1999) Regulation of peripheral cannabinoid receptor CB2 phosphorylation by the inverse agonist SR 144528. Implications for receptor biological responses. J Biol Chem 274:20397-20405. 
Bruley des Varannes S, Parys V, Ropert A, Chayvialle JA, Roze C, and Galmiche JP (1995) Erythromycin enhances fasting and postprandial proximal gastric tone in humans. Gastroenterology 109:32-39.

Camilleri M (2002) Motilin agonists and dyspepsia: throwing out the baby with the bath water. Gut 51:612; author reply 612-613.

Ciruela F, Saura C, Canela EI, Mallol J, Lluis C, and Franco R (1997) Ligandinduced phosphorylation, clustering, and desensitization of A1 adenosine receptors. Mol Pharmacol 52:788-797.

Depoortere I, Peeters TL, Matthijs G, Cachet T, Hoogmartens J, and Vantrappen G (1989) Structure-activity relation among macrolide antibiotics in inducing contractions and in displacing bund motilin in rabbit duodenum. Journal of Gastrointestinal Motility 1:150-159.

Depoortere I, Peeters TL, and Vantrappen G (1991) Effect of erythromycin and of octreotide on motilin receptor density in the rabbit. Regulatory Peptides 32:85-94.

Depoortere I, Verlinden M, Thijs T, Van Assche G, and Peeters TL (1999) The motilide ABT-229 selectively downregulates motilin receptors in different tissues. Evidence for motilin receptor subtypes. Gastroenterology 116:A1061.

Distrutti E, Azpiroz F, Soldevilla A, and Malagelada JR (1999) Gastric wall tension determines perception of gastric distention. Gastroenterology 116:10351042.

Ferguson SS (2001) Evolving concepts in G protein-coupled receptor endocytosis: the role in receptor desensitization and signaling. Pharmacol Rev 53:1-24. 
Filtz TM, Guan W, Artymyshyn RP, Facheco M, Ford C, and Molinoff PB (1994) Mechanisms of up-regulation of D2L dopamine receptors by agonists and antagonists in transfected HEK-293 cells. J Pharmacol Exp Ther 271:1574-1582.

Geurts M, Hermans E, and Maloteaux JM (1999) Enhanced striatal dopamine D(2) receptor-induced. Eur J Pharmacol 382:119-127.

Janssens J, Peeters T, Vantrappen G, Tack J, Urbain J, De Roo M., Muls E, and Bouillon R (1990) Improvement of gastric emptying in diabetic gastroparesis by erythromycin. Preliminary studies [see comments]. N Engl J Med 322:1028-1031.

Keith DE, Murray SR, Zaki PA, Chu PC, Lissin DV, Kang L, Evans CJ, and von Zastrow M (1996) Morphine activates opioid receptors without causing their rapid internalization. J Biol Chem 271:19021-19024.

Kenakin T (2002a) Drug efficacy at G protein-coupled receptors. Annu Rev Pharmacol Toxicol 42:349-379.

Kenakin T (2002b) Efficacy at G-protein-coupled receptors. Nat Rev Drug Discov 1:103-110.

Lartey PA, Nellans HN, Faghih R, Petersen A, Edwards CM, Freiberg L, Quigley S, Marsh K, Klein LL, and Plattner JJ (1995) Synthesis of 4"-deoxy motilides: identification of a potent and orally active prokinetic drug candidate. J Med Chem 38:1793-1798.

Lewis MM, Watts VJ, Lawler CP, Nichols DE, and Mailman RB (1998) Homologous desensitization of the D1A dopamine receptor: efficacy in causing 
desensitization dissociates from both receptor occupancy and functional potency. J Pharmacol Exp Ther 286:345-353.

Lowry DH, Rosenbrough MJ, Farr AL, and Randall RJ (1951) Protein measurement with the Folin fenol reagent. J Biol Chem 193:732-737.

Mahan LC, Koachman AM, and Insel PA (1985) Genetic analysis of betaadrenergic receptor internalization and down- regulation. Proc Natl Acad Sci U S A 82:129-133.

Omura S, Tsuzuki K, Sunazuka T, Marui S, Toyoda H, Inatomi N, and Itoh Z (1987) Macrolides with Gastrointestinal Motor Stimulating Activity. J.Med.Chem. 30:1941-1943.

Peeters TL, Matthijs G, Depoortere I, Cachet T, Hoogmartens J, and Vantrappen G (1989) Erythromycin is a Motilin Receptor Agonist. Am.J.Physiol. 257:G470G474.

Piessevaux H, Tack J, Wilmer A, Coulie B, Geubel A, and Janssens J (2001) Perception of changes in wall tension of the proximal stomach in humans. Gut 49:203-208.

Sternini C, Spann M, Anton B, Keith DE, Bunnett NW, von Zastrow M, Evans C, and Brecha NC (1996) Agonist-selective endocytosis of mu opioid receptor by neurons in vivo. Proc Natl Acad Sci U S A 93:9241-9246.

Szekeres PG, Koenig JA, and Edwardson JM (1998) The relationship between agonist intrinsic activity and the rate of endocytosis of muscarinic receptors in a human neuroblastoma cell line. Mol Pharmacol 53:759-765. 
Tack J and Peeters T (2001) What comes after macrolides and other motilin stimulants? Gut 49:317-318.

Talley NJ, Verlinden M, Snape W, Beker JA, Ducrotte P, Dettmer A, Brinkhoff H, Eaker E, Ohning G, Miner PB, Mathias JR, Fumagalli I, Staessen D, and Mack RJ (2000) Failure of a motilin receptor agonist (ABT-229) to relieve the symptoms of functional dyspepsia in patients with and without delayed gastric emptying: a randomized double-blind placebo-controlled trial. Aliment Pharmacol Ther 14:1653-1661.

Talley NJ, Verlinden M, Geenen DJ, Hogan RB, Riff D, McCallum RW, and Mack RJ (2001) Effects of a motilin receptor agonist (ABT-229) on upper gastrointestinal symptoms in type 1 diabetes mellitus: a randomised, double blind, placebo controlled trial. Gut 49:395-401.

Thielemans L, Depoortere I, Vanden Broeck J, and Peeters TL (2002) The motilin pharmacophore in $\mathrm{CHO}$ cells expressing the human motilin receptor. Biochem Biophys Res Commun 293:1223-1227.

Thompson AK and Fisher SK (1990) Relationship between agonist-induced muscarinic receptor loss and desensitization of stimulated phosphoinositide turnover in two neuroblastomas: methodological considerations. J Pharmacol Exp Ther 252:744-752.

Toews ML and Perkins JP (1984) Agonist-induced changes in beta-adrenergic receptors on intact cells. J Biol Chem 259:2227-2235.

Tsao P, Cao T, and von Zastrow M (2001) Role of endocytosis in mediating downregulation of G-protein-coupled receptors. Trends Pharmacol Sci 22:91-96. 
Verhagen MA, Samsom M, Maes B, Geypens BJ, Ghoos YF, and Smout AJ (1997) Effects of a new motilide, ABT-229, on gastric emptying and postprandial antroduodenal motility in healthy volunteers. Aliment Pharmacol Ther 11:10771086.

Yu Y, Zhang L, Yin X, Sun H, Uhl GR, and Wang JB (1997) Mu opioid receptor phosphorylation, desensitization, and ligand efficacy. J Biol Chem 272:2886928874.

Zaki PA, Keith DE, Thomas JB, Carroll FI, and Evans CJ (2001) Agonist-, antagonist-, and inverse agonist-regulated trafficking of the delta-opioid receptor correlates with, but does not require, G protein activation. J Pharmacol Exp Ther 298:1015-1020.

Zhang LJ, Lachowicz JE, and Sibley DR (1994) The D2S and D2L dopamine receptor isoforms are differentially regulated in Chinese hamster ovary cells. $\mathrm{Mol}$ Pharmacol 45:878-889. 


\section{Figure Legends}

Figure 1 Concentration dependent desensitization of the motilin receptor. Pretreatment of CHO-MTLR cells with motilin at the concentrations indicated, decreased the maximal $\mathrm{Ca}^{2+}$ response of a subsequent concentration response curve to motilin. The maximal response of the second stimulation is expressed as the percentage of control (no pretreatment) and is the mean \pm SEM of at least 3 experiments in duplicate.

Figure 2 A. Structure comparison of EM-A and ABT-229. Compared to EMA, ABT-229 contains an (1) enol configuration and (2) lacks hydroxyls on the 14 member lactone ring [12] and (3) on the cladinose [4'’] sugar. In addition (4), a methyl of the N-dimethyl amino group of the desosamine sugar has been replaced by an ethyl. B. ABT-229-like modifications in each motilide: the X indicates which of the four modifications represented in A is present.

Figure 3 Comparison of desensitization induced by different motilides. Cells were first stimulated with a motilide at $10^{-5} \mathrm{M}$ (X-axis) and the maximal response to a subsequent concentration-response curve to motilin was determined and expressed as a percent of control (no pretreatment). Each value represents the mean \pm SEM of at least 2 experiments in duplicate.

Figure 4 Concentration response curves of desensitization induced by motilin, ABT-229 and EM-A. Cells were pre-treated with different concentrations of the test compounds (x-axis) and the reduction in maximal response to a subsequent 
concentration response curve to motilin was calculated and expressed as a percent of control (y-axis). Each value is mean \pm SEM of at least 2 experiments in duplicate.

Figure 5 A. Comparison of the $\mathrm{Ca}^{2+}$ release evoked after concentrationdependent activation of wild type (top) and MTLR-EGFP (bottom) by motilin and motilides. Concentration response curves of motilin, ABT-229 and EM-A are expressed as percentage of Triton-X 100 values. B. Comparison of desensitization of wild type ( $\square$ ) and EGFP tagged MTLR ( $\square$ ) by motilin and motilides. The response to motilin after pretreatment with a ligand at $10^{-5} \mathrm{M}$ is expressed as percentage versus control (no pretreatment). Values are mean \pm SEM of 3 experiments in duplicate.

Figure 6 A. Fluorescence imaging of MTLR-EGFP trafficking of the expressed in $\mathrm{CHO}-\mathrm{K} 1$ cells before (top panel) and after (bottom panel) stimulation with agonists $\left(10^{-5} \mathrm{M}\right)$ for $1 \mathrm{~h}$ at $37^{\circ} \mathrm{C}$. Before treatment, fluorescence is mainly located at the cell surface, while relocation to the cytosol took place after treatment with motilin, EM-A and ABT-229. B. Quantification of the change in fluorescence distribution between the cell surface and the cytosol after stimulation with motilin, EM-A or ABT-229. Three different sets of cells were stimulated with the same ligand. The change in fluorescence was measured in 10 cells per set. Values were expressed as mean \pm SEM. \#, p < 0.0001 vs. control; *, $\mathrm{p}<0.01$ vs. ABT-229; **, $\mathrm{p}<0.01$ vs. motilin and $\mathrm{p}<0.0001$ vs. control. 
Figure 7 Residual binding of ${ }^{125}$ I- motilin at the surface of MTLR-EGFP cells pre-treated with motilin agonists at $10^{-5} \mathrm{M}$ for 20 or $60 \mathrm{~min}$. Results are expressed as percentage residual binding versus non-treated cells (mean \pm SEM, $n=3$ in duplicate). ${ }^{* *}, \mathrm{p}<0.0001$ vs. control and $* *, \mathrm{p}<0.005 ; *, \mathrm{p}<0.05$ vs. motilin.

Figure 8 Contractility study. Repeated applications of motilides to rabbit duodenal muscle strips result in decreased contractility. For each motilide, this is expressed as percentage of the contractility that occurred during the first application. 
Table 1

\begin{tabular}{|c|c|c|c|c|}
\hline & $\mathrm{pEC}_{50} \pm \mathrm{SEM}$ & $\mathrm{plC}_{50} \pm \mathrm{SEM}$ & $\mathrm{pDC}_{50} \pm \mathrm{SE}$ & $\mathrm{pEC}_{50}-\mathrm{pDC}_{\mathbf{5 0}} \pm \mathrm{SE}$ \\
\hline Test method & Luminescence & Binding & Desensitization & Delta \\
\hline motilin & $9.39 \pm 0.03$ & $8.55 \pm 0.05$ & $7.77 \pm 0.08$ & $1.62 \pm 0.15$ \\
\hline ABT-229 & $8.46 \pm 0.08$ & $7.23 \pm 0.10$ & $8.78 \pm 0.03$ & $-0.32 \pm 0.16$ \\
\hline EM-A & $7.11 \pm 0.05$ & $5.51 \pm 0.10$ & $4.78 \pm 0.26$ & $2.33 \pm 0.28$ \\
ME36 & $6.62 \pm 0.02$ & $4.65 \pm 0.06$ & $3.32 \pm 0.15$ & $3.30 \pm 0.16$ \\
\hline ME4 & $8.08 \pm 0.01$ & $6.27 \pm 0.13$ & $5.90 \pm 0.42$ & $2.18 \pm 0.42$ \\
\hline ME67 & $8.12 \pm 0.10$ & $6.49 \pm 0.10$ & $6.03 \pm 0.10$ & $2.09 \pm 0.25$ \\
EM-523 & $8.22 \pm 0.01$ & $6.59 \pm 0.06$ & $6.02 \pm 0.28$ & $2.20 \pm 0.28$ \\
\hline KOS1326 & $8.14 \pm 0.16$ & $7.16 \pm 0.08$ & $7.32 \pm 0.0002$ & $0.82 \pm 0.28$ \\
\hline & & & & \\
\hline
\end{tabular}


Figure 1

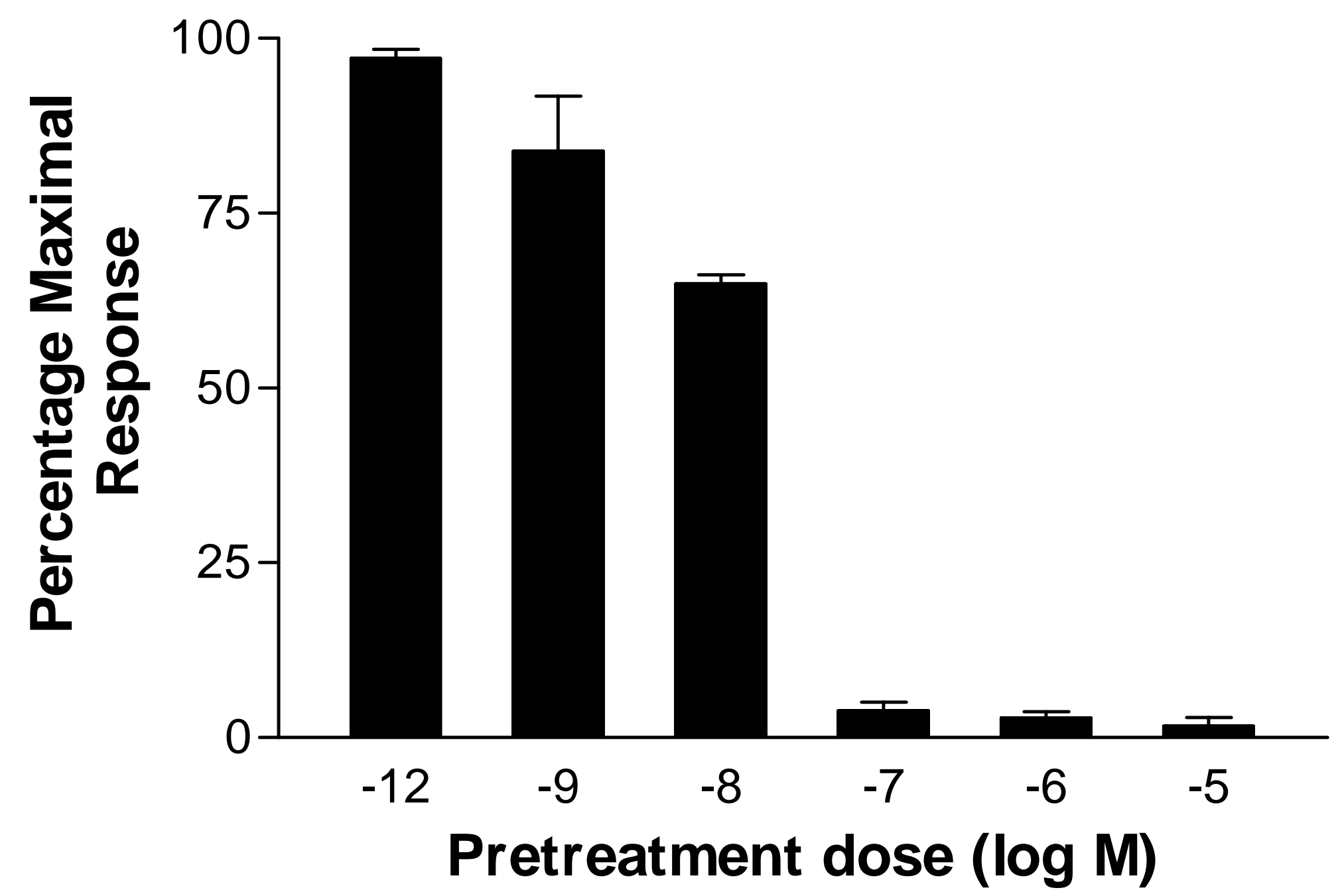




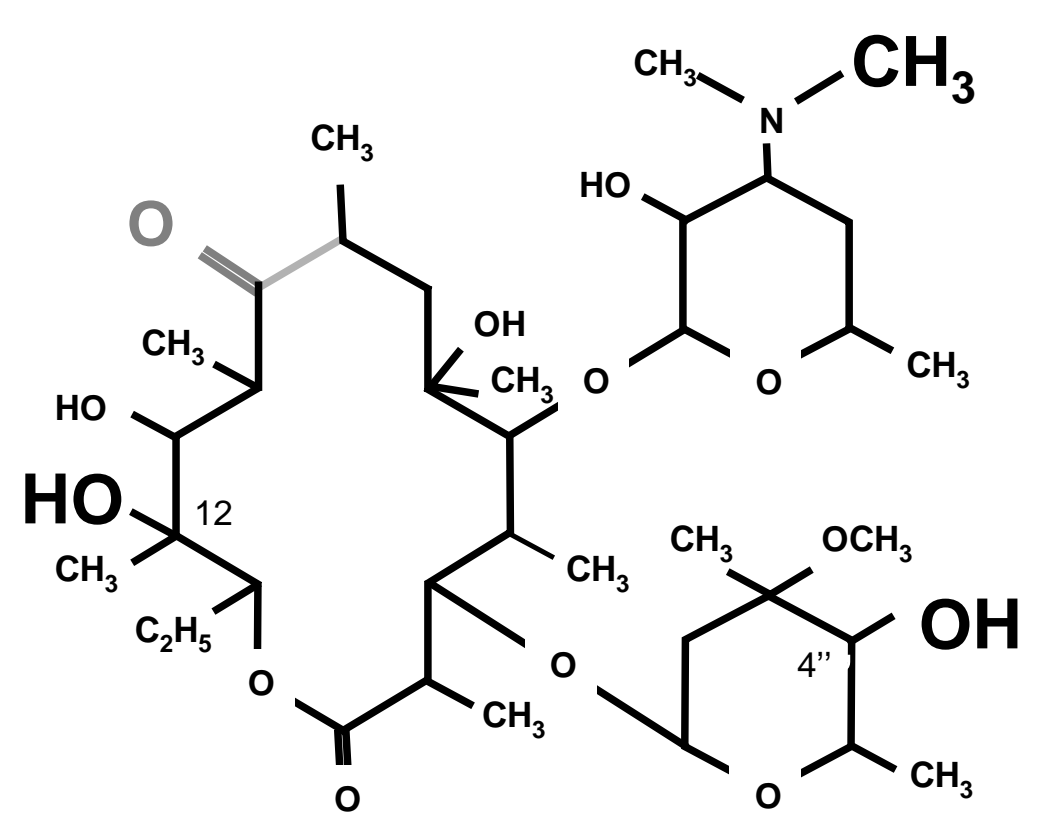

Erythromycin-A

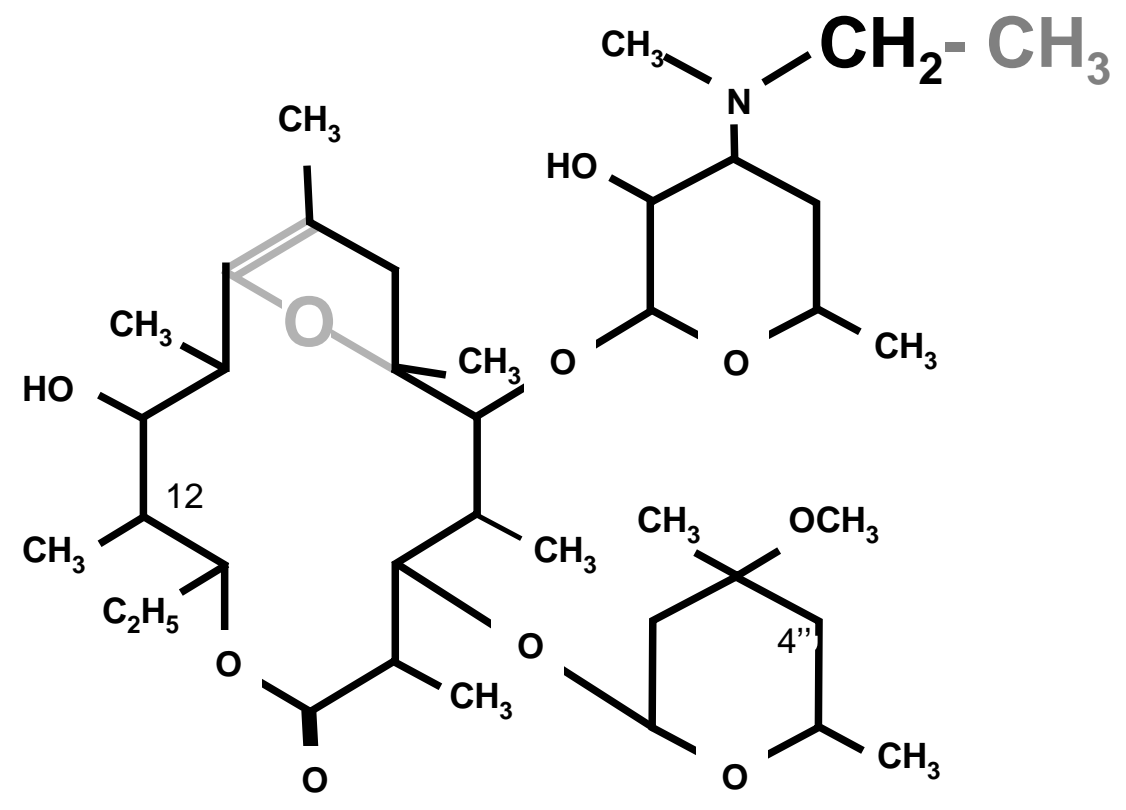

ABT-229

\begin{tabular}{|l|c|c|c|c|}
\hline & ENOL & 12-OH & ETHYL & 4"'-OH \\
\hline EM-A & & & & \\
ME36 & & & $X$ & \\
ME4 & $\mathrm{X}$ & & & \\
ME67 & $\mathrm{X}$ & $\mathrm{X}$ & & \\
EM-523 & $\mathrm{X}$ & & $\mathrm{X}$ & \\
KOS1326 & $\mathrm{X}$ & & & $\mathbf{X}$ \\
ABT-229 & $\mathbf{X}$ & $\mathbf{X}$ & $\mathbf{x}$ & $\mathbf{X}$ \\
\hline
\end{tabular}

Figure 2 
Figure 3

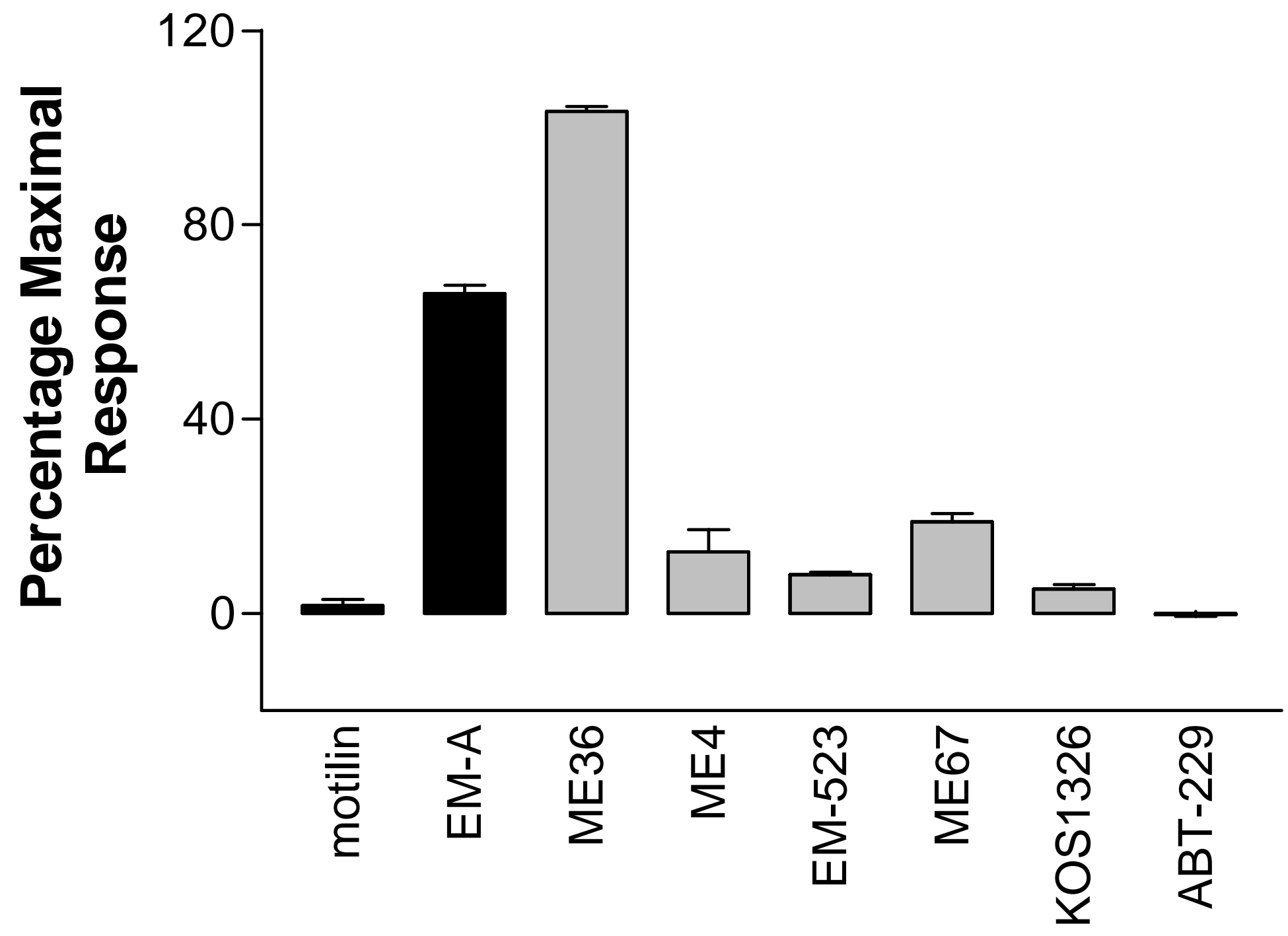

First stimulus at $10^{-5} \mathrm{M}$ 
Figure 4

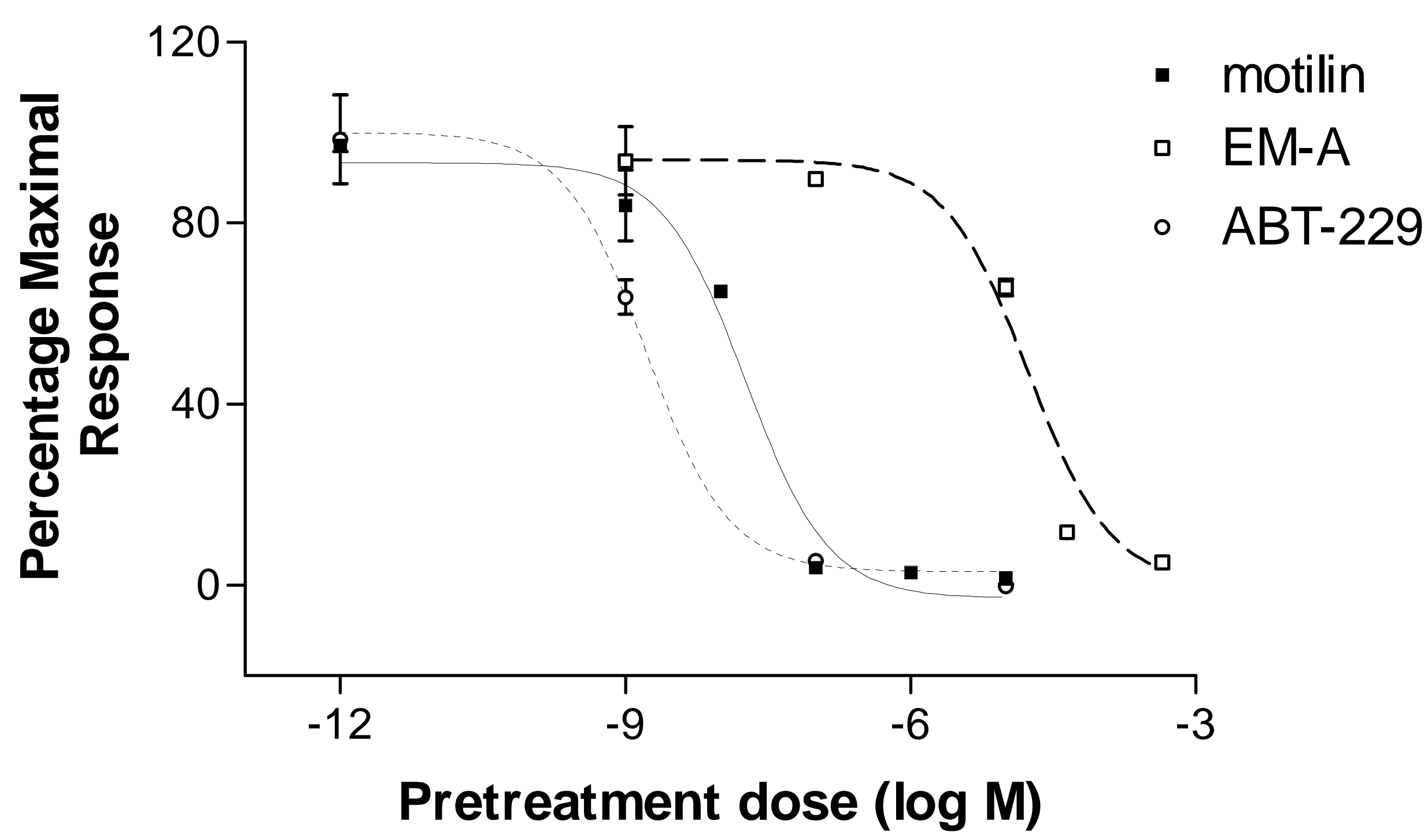


Figure 5

\section{A Activation}
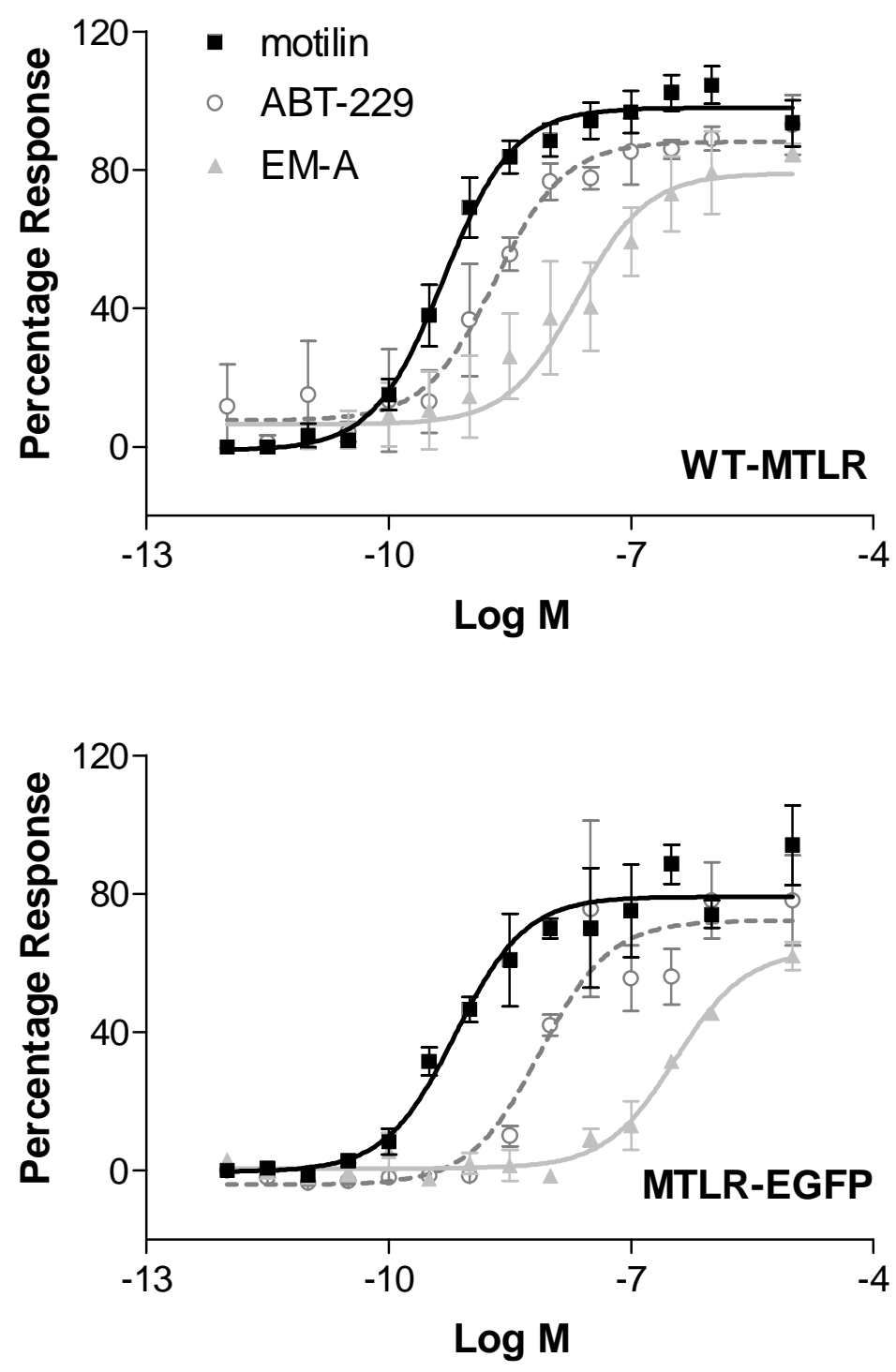

B Desensitization

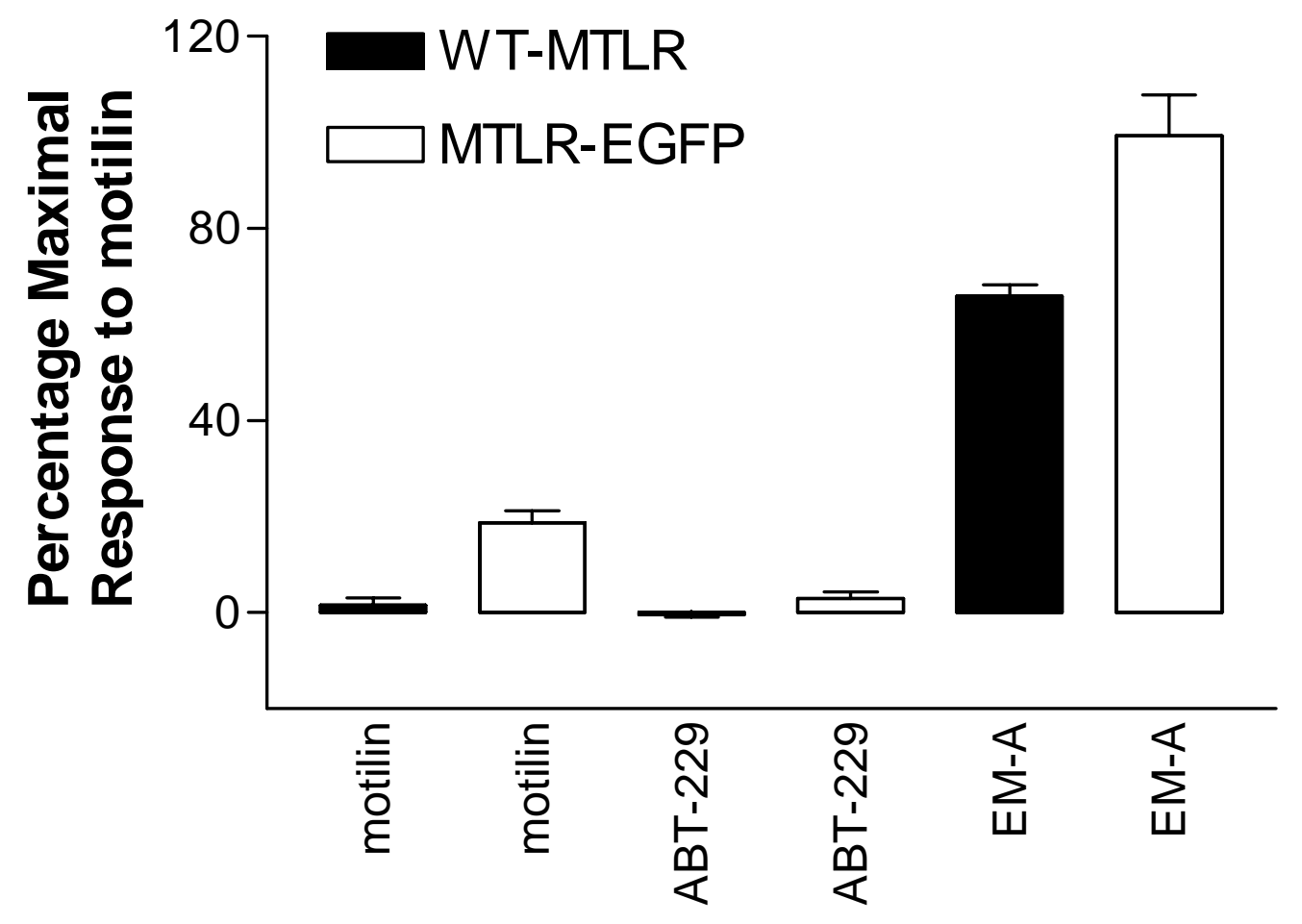

First stimulus 
Figure 6

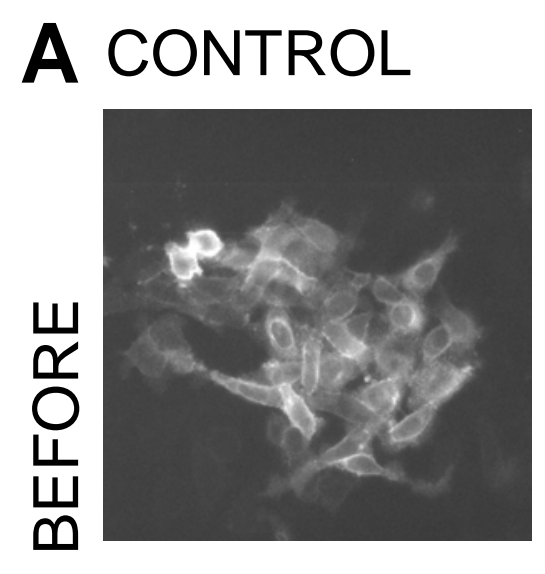

MOTILIN
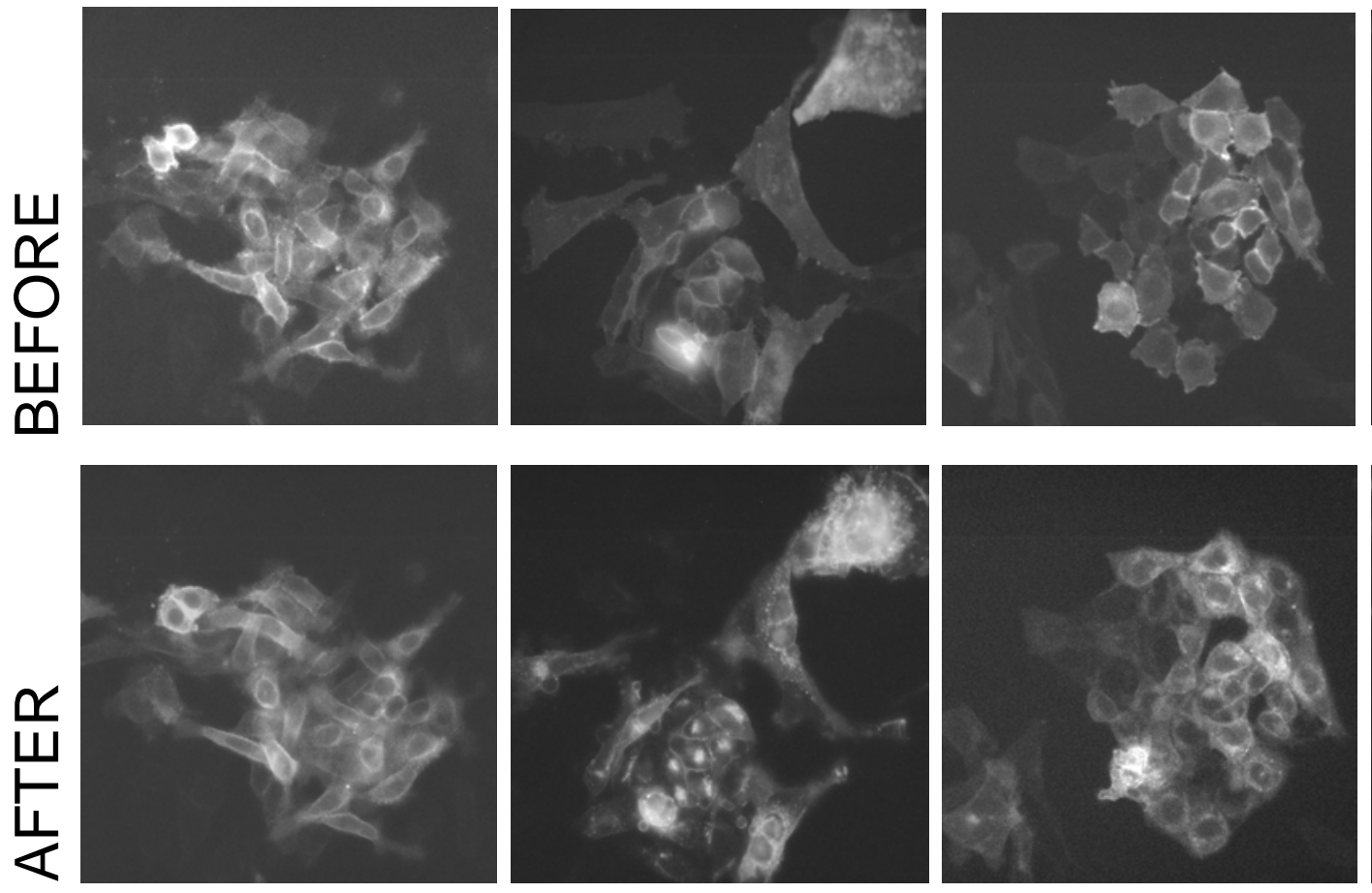

EM-A

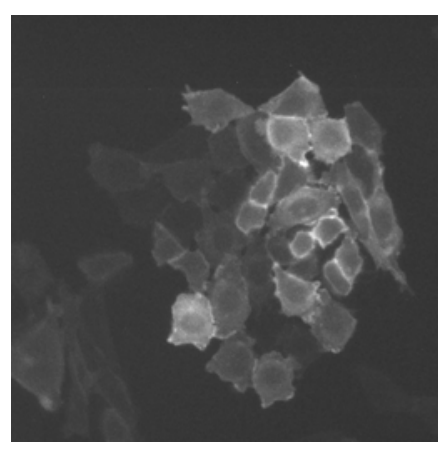

ABT-229
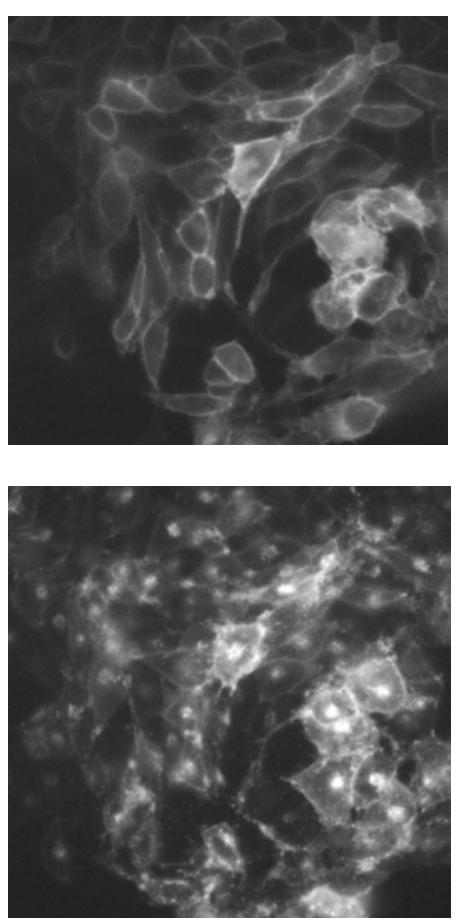

B

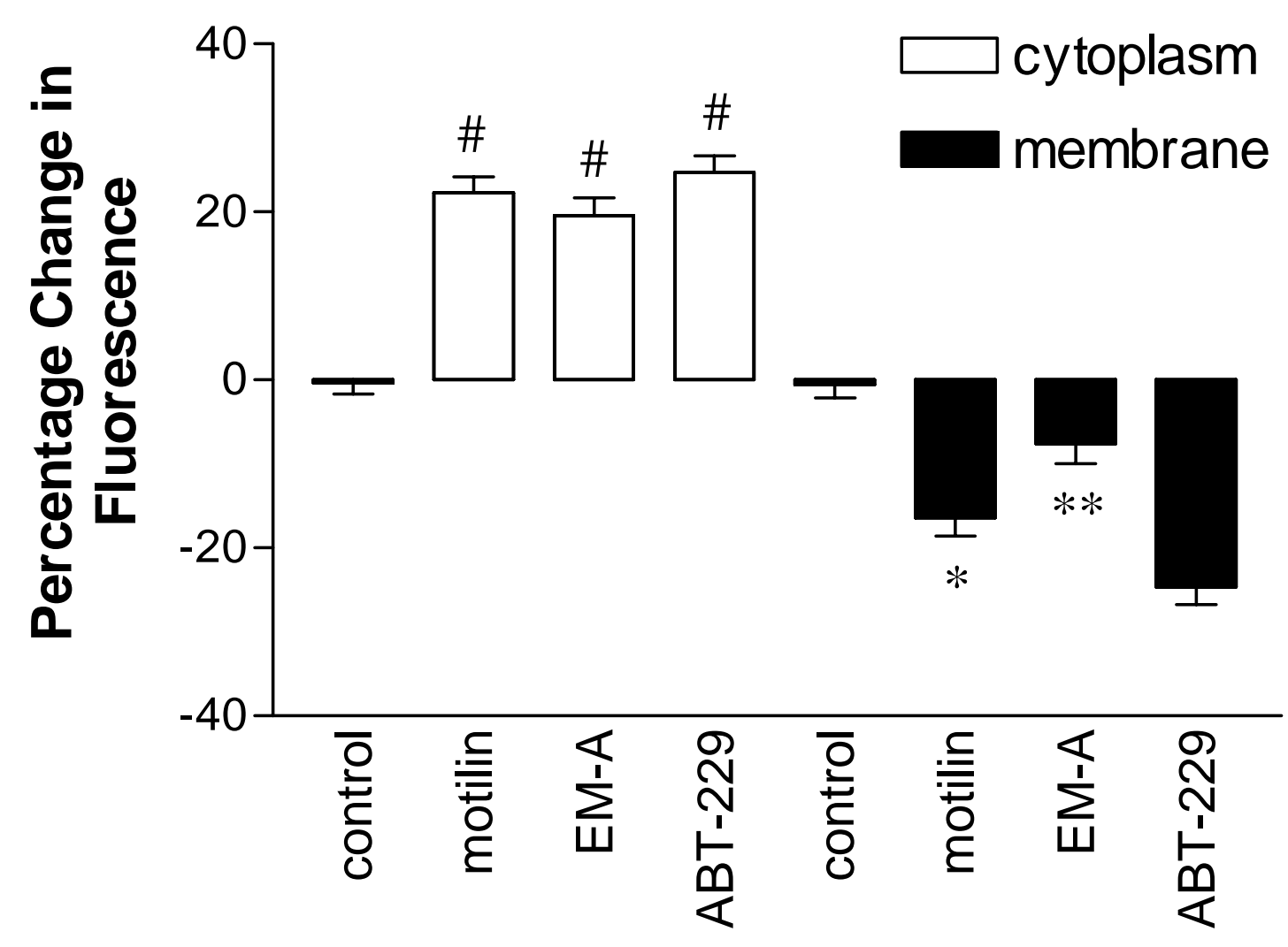


Figure 7

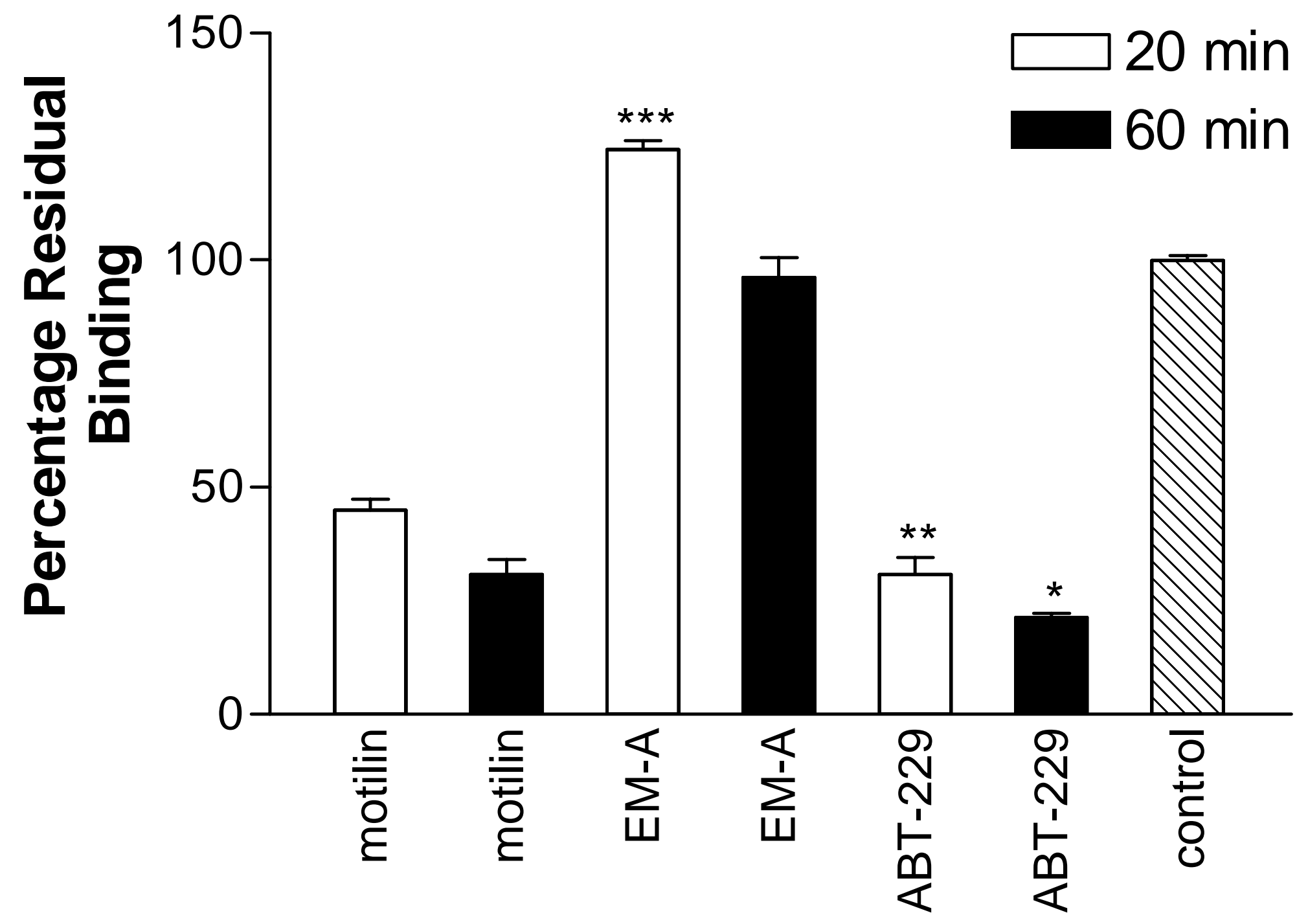


Figure 8

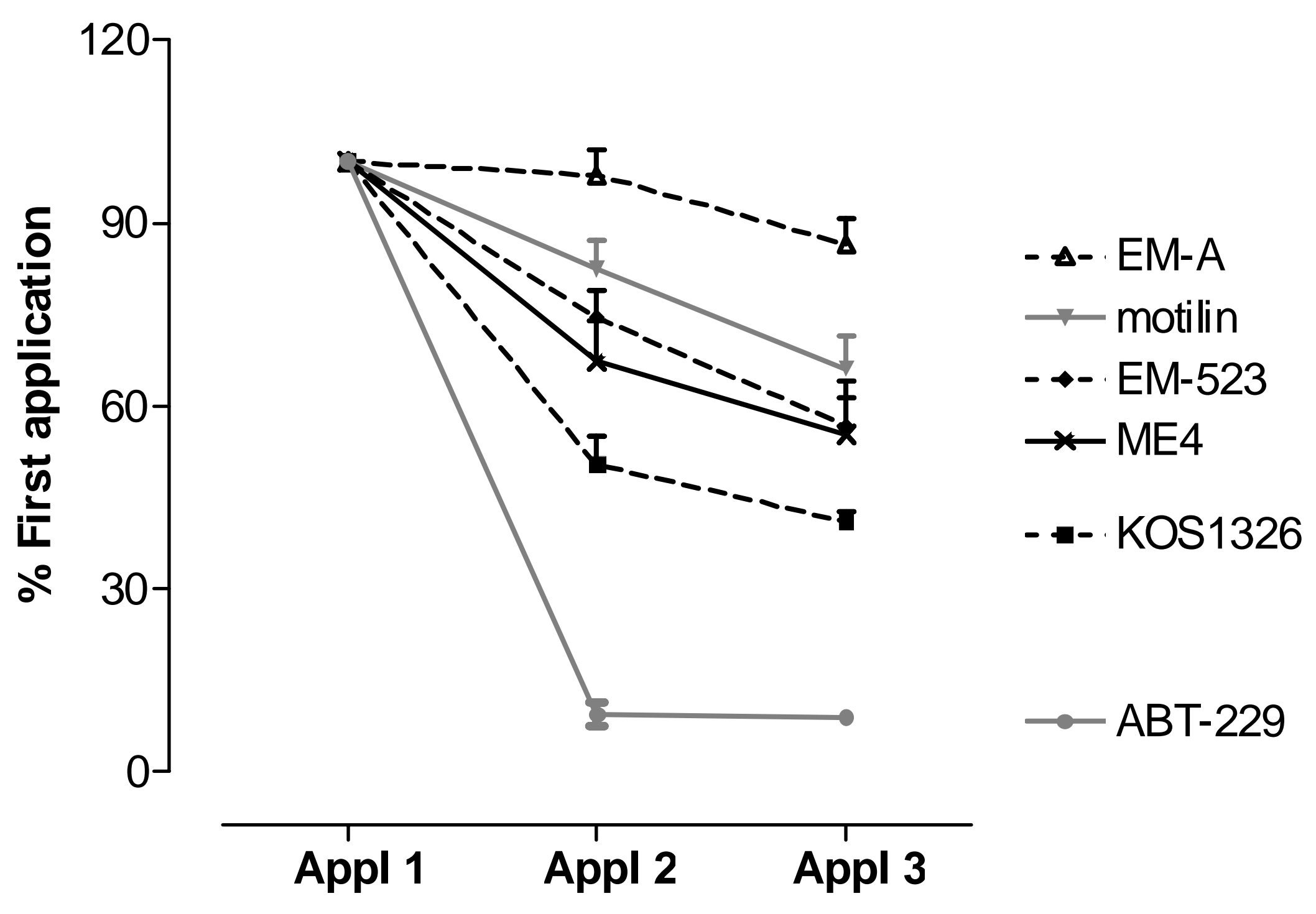

